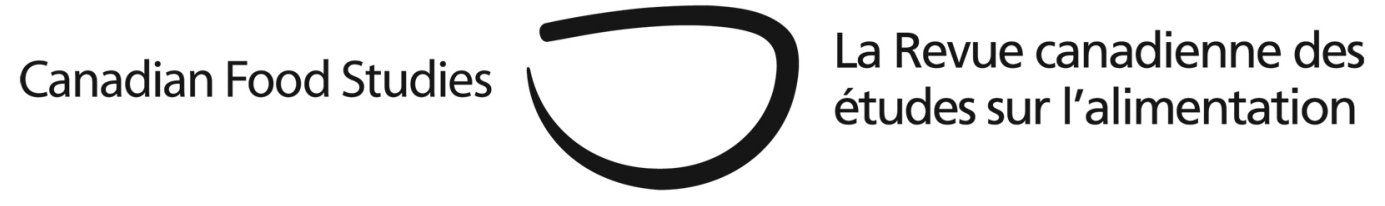

Original Research Article

\title{
Planning for food sovereignty in Canada? A comparative case study of two rural communities
}

\author{
Virginie Lavallée-Picard \\ Department of Parks, Recreation, and Culture, City of Victoria
}

\begin{abstract}
In Canada, most local-governance-level food system planning research has been conducted in larger, often urban communities. However, producers in small rural communities conduct the majority of Canada's agricultural activities. Using case study research, this paper documents how the rural communities of Saint-Camille (Québec) and Salt Spring Island (British Columbia) engage in food system planning. By investigating background issues, key achievements, barriers, and best practices, the case studies inform a comparative analysis of governance planning processes and community-led project development. The results suggest an overlap between the community food system planning framework and the food sovereignty framework, a space discerned as food sovereignty planning.
\end{abstract}

Keywords: local food, food system, local government, food system planning, food sovereignty planning, Salt Spring Island, Saint-Camille.

Acronyms:

AFP: Area Farm Plan

ALC: Agricultural Land Commission

ALR: Agricultural Land Reserve 
CDSE: Corporation de développement socio-économique de Saint-Camille (non-profit community development organization of Saint-Camille)

CPTAQ: Commission de protection du territoire agricole du Québec (Québec commission for the protection of agricultural land)

LPTAA: Loi sur la protection du territoire et des activités agricoles (law on the protection of agricultural land and activities)

MIR: Meat Inspection Regulation

MRC: Municipalité régionale de comté (administrative entity comprising multiple municipalities)

OCP: Official Community Plan

PDZA: Plan de développement de la zone agricole (MRC-focused agricultural development plan)

SSI: Salt Spring Island

SSIAA: Salt Spring Island Agricultural Alliance

UPA: Union des producteurs agricoles (union of Québec agricultural producers)

Introduction: Community food system planning in Canada

In Canada, most food system issues have traditionally been interpreted to be provincial and federal matters. The jurisdictional authority of local governments over the food system is limited, yet local governments are directly faced with the consequences of food system issues. These include the local effects of climate change and pollution, food insecurity, diet-related public health problems, loss of agricultural land, shifting population and demographics, financial struggles of food producers, shrinking local food infrastructures and support services, and decreasing employment and tax revenues from agrifood enterprises. As the level of governance closest to the community and as a service provider, local governments have the power to educate, to support local initiatives, enact policies, and develop programs that can shape the local food system and respond to the specific needs of their citizens.

Until recently food system considerations had been largely absent from municipal planning (Pothukuchi, 2000; Pothukuchi \& Kaufman, 1999; Raja, Born, \& Purcell, 2008). Today community food system planning is generally understood as the integration of food system considerations into community project, planning process, and policy development, with the goal of improving a community's food system (Raja et al., 2008). The American Planning Association (2013) more specifically defines community food system planning on its website as:

...the collaborative planning process of developing and implementing local and regional land-use, economic development, public health, and environmental goals, programs and policies to: Preserve existing and support new opportunities for local and 
regional urban and rural agriculture; Promote sustainable agriculture and food production practices; Support local and regional food value chains and related infrastructure involved in the processing, packaging, and distribution of food; Facilitate community food security, or equitable physical and economic access to safe, nutritious, culturally appropriate, and sustainably grown food at all times across a community, especially among vulnerable populations; Support and promote good nutrition and health, and; Facilitate the reduction of solid food-related waste and develop a reuse, recovery, recycling, and disposal system for food waste and related packaging.

Pothukuchi \& Kaufman (1999) identify five approaches by which municipal planners can engage in food system planning: 1) the compilation of data on the community food system; 2) the analyses of connections between food and other planning concerns; 3 ) the assessment of the impact of current planning on the local food system; 4) the integration of food security into community goals; and 5) the education of future planners regarding food system issues. The field of food system planning is rapidly evolving as a growing body of research and planning tools improve our understanding of complex food systems, identify opportunities and challenges, and evaluate the efficacy of food system planning (Freedgood, Pierce-Quinonez, \& Meter, 2011; Meter, 2011; de la Salle, \& Holland, 2010).

In Canada, most efforts to document and research food system planning at the localgovernance level have focused on larger, often urban communities (see the work of Apparicio, Cloutier, \& Shearmur, 2007; Blay-Palmer, 2009; Larsen \& Gilliland, 2008; Mendes, 2007; Mendes, 2008; Smoyer-Tomic et al., 2006). Some research, like that of Desjardins, Lubczynski, and Xuereb (2011), which considers the relationship between rural and urban land use policies in the Waterloo Region, has included both the rural and urban context. Yet to date, little research on food system planning has been conducted in the small rural communities where farmers live and undertake the majority of Canada's agricultural activities. Conducting research on rural communities is relevant not only because the land base under their jurisdiction produces the vast majority of Canada's agricultural products, but also because there are significant opportunities unique to rural communities to develop innovative forms of resistance, community building, and social movements (Wittman, 2009; Woods, 2003).

To explore the involvement of small, rural communities in food system planning, this paper uses case study research to document how Saint-Camille (Québec) and Salt Spring Island (British-Columbia) engage in food system planning. These communities were primarily selected because they were already known to be "hot spots" of community-driven local food system development; they are not representative of a broad trend. Both case studies are based upon a review of various reports, published works, and site visits, as well as twelve phone and in-person interviews. Qualitative data analysis software was used to identify key themes. The Salt Spring Island research was primarily conducted in the summer of 2012; the Saint-Camille research was, for the most part, undertaken in the winter of 2013. The investigation of background issues, key 
achievements, barriers, and best practices, informs a comparative analysis of local governance planning processes and community-led project development. This comparative analysis feeds into an exploration of how Saint-Camille and Salt Spring Island's (SSI) food system planning initiatives reflect key food sovereignty themes. In this context, food sovereignty is understood as:

“...the right of peoples to healthy and culturally appropriate food produced through ecologically sound and sustainable methods, and their right to define their own food and agriculture systems" (Nyéléni Declaration, Mali, 2007).

Generally speaking, food sovereignty is a widely hypothesized theory of change seeking to alleviate the linked challenges of environmental degradation and global food insecurity by reconnecting the politics of local food to socio-ecological practices of food production and consumption (Carney, 2012; Desmarais, 2002; 2008; Patel, 2009; Wittman, 2009; Wittman, Desmarais, \& Wiebe, 2010; 2011)

\section{Salt Spring Island}

Located in the Strait of Georgia off the eastern shore of Vancouver Island, and with a population of approximately 10,000 people, SSI is the largest and most populated island of the Southern Gulf Islands region. In the mid-1800s, European settlers established dairy, fruit, poultry, sheep, and animal-feed farming operations to supply neighboring Victoria, but production declined significantly after World War II. An agricultural revival in the 1970s and 1980s saw the emergence of small-scale (often organic) agricultural enterprises. More recently, small-scale farming has experienced renewed growth. Still, local food production is insufficient to feed the local population thus large international distributors bring in the majority of the food sold on the island. The cost of food and agricultural inputs are exacerbated by the reliance on ferry or plane transportation (Reichert, 2006). 2006 land-use data suggests that a substantial amount of SSI's arable land was not being actively farmed: 15 percent (2,920 ha) of the SSI land area was part of the Agricultural Land Reserve (ALR), only 54 percent of which was actively being farmed (Ministry of Agriculture and Lands, 2006). ${ }^{1}$ The ALR is a provincial land use zoning designation applied to land with agricultural capabilities. Its purpose is to ensure the preservation of BC's small agricultural land base. The ALR is administered by the Agricultural Land Commission (ALC), an independent government agency created by the 1973 ALC Act to preserve agricultural land, promote farming, and encourage BC local governments to enable and accommodate farming in plans, bylaws, and policies. ${ }^{2}$

\footnotetext{
${ }^{1}$ This is in part because BC Parks owns more ALR land on SSI than any other landowner (with Ruckle Farm being the exception), and farming is not permitted in BC Parks.

${ }^{2}$ Farming operations are also protected through BC's Right to Farm legislation from being sued for nuisance-type impacts resulting from normal farm practices. This limits the extent to which local governments can regulate and restrict certain agricultural activities.
} 
Amendments to the provincial Meat Inspection Regulation (MIR) are widely viewed as an important cause of the drastic decline in livestock raised on SSI. By 2010 the total number of animals (including sheep, cattle, pigs, and goats) had decreased by approximately 44 percent since 2004-05, while the total number of poultry sold for meat had decreased by approximately 52 percent since 2004 (Reichert \& Thomson, 2010). Enacted in 2004, the amended MIR introduced standards that made existing, non-licensed abattoirs or on-farm slaughtering practices illegal, thereby requiring that all slaughtering to produce meat for sale for human consumption take place in licensed facilities. Because there were no licensed abattoirs on SSI, the regulations required farmers to transport live animals off island by ferry to a licensed plant and then to return to the abattoir at a later time to retrieve the meat.

\section{Key food planning achievements}

SSI is under the jurisdiction of the Capital Regional District and is part of the Islands Trust, a federation of independent local governments. Locally elected representatives from the SSI Local Trust Council, which directs the development of official community plans, zoning, and other land-use planning and bylaws on SSI. In 2005 the SSI Agricultural Advisory Committee recommended the development of an Area Farm Plan (AFP). ${ }^{3}$ The SSI Farmer's Institute and the community organization Island Natural Growers, in collaboration with the SSI Local Trust Council and the BC Ministry of Agriculture and Lands, completed the AFP in January 2008. A local consulting firm facilitated community dialogue sessions and drafted the AFP under the direction of a Steering Committee. The AFP's guiding vision was for SSI to become "a place where agriculture is a strong, vital and productive part of the local economy and is carried out in a manner that promotes and protects a sustainable community” (Masselink Environmental Design, 2008, p.5). Of 25 recommendations, three emerged as priorities:

1. Establish a Salt Spring Agricultural Alliance...to assume the responsibility of the implementation of the AFP... and provide a central contact point and coordinating role for agricultural matters on or involving Salt Spring Island.

2. Establish a community farmland trust...that can accept, acquire and manage farmland and ensure that it is farmed in perpetuity.

3. Establish key community facilities that support the expansion of agricultural activities...[including] an abattoir and cold storage, processing and composting facilities on Salt Spring” (Masselink Environmental Design, 2008, p.5).

\footnotetext{
${ }^{3}$ In British Columbia, the Agricultural Land Commission and the Ministry of Agriculture support local governments in developing Agricultural Area Plans, which are also known as Agricultural Farm Plans (AFP). These plans focus on discovering practical solutions and opportunities to strengthen farming in a community's farm area so as to contribute to long-term sustainability (BC Ministry of Agriculture, n.d.).
} 
Established in November 2008, the SSI Agricultural Alliance (SSIAA) now plays an advocacy role in local agricultural issues and policy, and has been the driving force behind the planning and development of the SSI Agriculture Infrastructure Project, whose goal is to support the expansion of agriculture on SSI by developing an abattoir, a produce centre, and a community composting facility. To overcome the challenges posed by the revised MIR, the SSIAA championed the development of the SSI Abattoir, whose \$475,000 capital budget was obtained from the provincial Meat Transition Assistance Program and by raising more than $\$ 300,000$ from the community. The SSI community, through the SSIAA, owns the assets of the abattoir; the Salt Spring Abattoir Society has been set up to run operations. The abattoir has been in operation processing lamb and poultry since September 28, 2012, with beef and pork to be added in 2016.

In 2012 the SSIAA offered public drop-off sites for clean woody debris to produce gardening mulch, and work to implement a more comprehensive composting pilot project is ongoing.

The SSI Farmland Trust was established in 2009 to help the community to effectively address the problem of an eroding farm base and to provide opportunities for new farmers by creating access to affordable land. The SSI Farmland Trust is transforming (drainage, fencing, irrigation infrastructure, etc.) the Fulford Property, Burgoyne Valley Community Farm, and a gifted piece of agricultural land into a food-producing site for the SSI community. In 2012 the Shaw Family Community Gardens occupied six of the 62 acres of the Burgoyne Valley Community Farm. The remaining acreage is now home to five small farms, whose land base is rented from the SSI Farmland Trust on long-term leasing agreements. Most of the farmers are younger people starting new farms.

The SSIAA and the SSI Farmland Trust are jointly driving the development of the Center for Food Security (previously known as the "SSI Farm Produce Centre”). Described as a multipurpose facility and social enterprise, the Centre for Food Security will operate as a nonprofit organization on a cost recovery basis. The Centre aims to develop and model a type of consolidated agricultural infrastructure designed to increase local food production and facilitate both retailing and wholesaling of local foods. The Centre will provide multiple services, including: a produce storage, aggregation, distribution, and processing centre; an educational space; permaculture and greenhouse demonstration sites; honey extraction equipment; and a seed bank. It is anticipated that the Centre for Food Security will facilitate commercial distribution, develop co-branding and joint ventures, provide incubator services for product development, and serve as a hub for small equipment rental, office space, workshops and mentoring, marketing support, an agricultural information clearinghouse, and a CSA coordination and distribution station (Reichert, 2012). Site development commenced in 2016 on a property acquired by the SSI Farmland Trust and situated on Beddis Road, a heritage agricultural area of the island. Other community organizations involved in the visioning and future operations of the Centre include SSI Community Services, SSI Conservancy, and SSI Seed Sanctuary. 


\section{Saint-Camille}

Situated in the Estrie region east of Montreal, Saint-Camille was a thriving agricultural community at the beginning of the twentieth century. Its population reached 1290 citizens in 1914, but dropped to 610 in 1972 and then to 450 by 1984 (Béïque, 2011). This population decrease has been attributed to ongoing centralization and concentration of commercial activities and services, as well as the restructuring of agriculture-all of which drove migration from the countryside to the cities. Today, the agriculture, forestry, fishing, and hunting sector account for the majority of local employment, and 92 percent of Saint-Camille's territory is zoned as “agricultural” (Dufresne, 2012). Aside from a few relatively diversified and organic farming operations, conventional agriculture is the dominant model, with dairy and cash cropping being the most common forms of production.

Saint-Camille is one of the seven towns and villages that together make up the Municipalité Régionale de Comté “Des Sources.” A “Municipalité régionale de comté” (MRC), or regional county municipality, is an administrative entity that brings together municipalities within a given territory to oversee planning and development and ensure conformity with provincial laws and regulations (MAMROT, 2012). In 2009, as recommended in the Pronovost report, ${ }^{4}$ the Québec Ministry of Fisheries, Food, and Agriculture supported the elaboration of the first MRC-focused agricultural zone development plan ("Plan de développement de la zone agricole,” or PDZA). The MRC des Sources finalized its PDZA in June 2014.

In 1978, the Québec government adopted a law ("Loi sur la protection du territoire et des activités agricoles”, or LPTAA) to protect valuable agricultural land. The Québec commission for the protection of agricultural land ("Commission de protection du territoire agricole du Québec”, or CPTAQ) oversees the application of the LPTAA, evaluates requests, and grants authorizations for non-agricultural land-use activities and zoning modifications, and counsels the provincial government on matters relating to the protection of agricultural land (CPTAQ, 2007). Enacted in 2001, Law 184 included Article 59, under which MRCs can present a collective demand to the CPTAQ for residential functions to be introduced into properties that are zoned as agricultural. The "Union des Producteurs Agricoles” (UPA), a producer union representing Québec agricultural producers on a mandatory basis, can intervene in any request presented to the CPTAQ.

\footnotetext{
${ }^{4}$ In June 2006, the “Commission sur l'avenir de l'agriculture et de l'agroalimentaire québécois” (the Québec Commission on the Future of Agriculture and Agri-Food) was formed to identify issues facing, examine the efficacy of policies and programs targeting, and formulate recommendations regarding Québec's agriculture and agrifood sectors. In January 2008 the Commission published its results in what came to be known as the Pronovost Report. The issues identified by the report included decreasing agricultural revenues, unprecedented producer debt loads, increased costs of financial aid programs, challenges in transferring farms to a new generation, market prices that do not reflect increasing production costs, relative lack of consumer confidence in the sector, increased pressure to further liberalize agricultural markets, increased psychological distress among producers, weakened growth prospects, and a highly structured and concentrated food distribution system (Pronovost, 2008).
} 


\section{Key food planning achievements}

In 2003, a non-profit community development organization (the "Corporation de développement socio-économique de Saint-Camille,” or CDSE), which was founded in 1994 by a group of citizens, was mandated by the municipality to develop and implement a plan to increase the population of the village by 10 percent in 10 years. By 2011, the Saint-Camille population had reached 511 residents, a 14 percent increase from 2006 (Dufresne, 2012). Initiatives promoting agricultural diversification, increasing community food autonomy, and diversifying the real estate market have contributed to surpassing the demographic objective.

In 1999, the CDSE founded "Le salon régional d'animation sur la diversification agricole de Saint-Camille" (hereafter referred to as "the Salon"), a local, recurring conference focused on agricultural diversification. Two conditions affecting the future of agriculture were said to have helped shape and garner community support for the Salon: 1) a productivist and monocultureoriented model was being developed to the detriment of family farms; and 2) a growing disconnect between the countryside and the village, whereby both agricultural inputs and outputs no longer contributed to fabric of, and the social and economic interaction between farms and the village. In the Saint-Camille context, agricultural diversification involved occupation of the agricultural territory with individuals and enterprises that intensively operate agro-ecological enterprises on small land parcels, and investing in types of production that allow more people to settle in the area. It also involved developing business models designed around local consumption and the creation of niche products and agro-tourism. Held on a biannual basis until 2013, the Salon shed new light on how agriculture is linked to sustainable ways of living, producing, and consuming. ${ }^{5}$ Currently, instead of organizing a Salon every two years, activities and workshops relating to agricultural diversification are offered on an annual, continuous basis. ${ }^{6}$

The solidarity cooperative ${ }^{7}$ La Clé des Champs emerged from the convergence of ideas explored in previous Salons and a short course in applied ethics that examined citizen responsibility in community vitalization. The co-op was officially formed in 2003, shortly after a community leader made his land available to a group interested in the development of a community market garden as a means to achieve greater community food autonomy. Its goals were to: support the new farming generation by providing access to collective property; promote a diversity of new farming enterprises; support the local community in safeguarding the agricultural and rural patrimony; and contribute to the transmission of knowledge (Béique, 2011). Founding principles also included job creation and the production and availability of

\footnotetext{
${ }^{5}$ For example, the first Salon explored strategies to support the new farming generation, whereas a later edition focused on renewable energy.

${ }^{6}$ For example, in the fall of 2015 and the winter of 2016, the CDSE helped organize multiple one-day events touching on diverse topics including recent innovations in the agrifood sectors, hop production, milkweed cultivation, and the Trans-Pacific Partnership.

${ }^{7}$ The membership of solidarity co-operatives is composed of user-members, worker-members, and support or community-members. Because it brings together all parties involved in a particular endeavour, solidarity cooperatives are sometimes referred to as "multi-stakeholder cooperatives."
} 
products derived from local agriculture and forestry (Lair, 2011). In 2004, the co-op grew another branch focused on gathering non-woody forest products, “Cultur'Innov,” which soon after became a separate cooperative entity offering consulting services pertaining to agroforesty and the production of new specialty crops. By 2011, the co-op operated on seven rented acres, had acquired several agricultural assets, had hired five employees, and had obtained financing from various provincial and local entities (Lair, 2011). In 2012, La Clé des Champs was sold ${ }^{8}$ to two young farmers, thus becoming a private enterprise, which nonetheless continues to play a central role in Saint-Camille's food autonomy. In 2016, Cultur'Innov continues to operate as a co-op and is working with the CDSE to develop an experimental orchard to research and develop new specialty crops.

To attract newcomers, the CDSE and the municipality spearheaded two innovative real estate development projects. Initiated in 2004, the Parc AgroVillageois project is a development model that is both close to the heart of the village and open to the agricultural landscape. One interviewee explained, "We noticed that people liked to settle around a lake, so we thought why not settle around a garden... a food pantry?” To conserve agriculturally productive land while featuring its nourishing and agricultural characteristics, the development was to be situated within the forested borders of cultivated lands used by La Clé des Champs. A plan to divide this agricultural property into 17 one-acre forested parcels was devised. A collective demand to modify the zoning from agricultural to non-agricultural was submitted to the tripartite evaluation process involving the MRC, the UPA, and the CPTAQ. The UPA argued that the de-zoning would fracture and expand the development of the village and set a bad land-use planning precedent. A compromise was eventually struck whereby land that had previously been de-zoned for the construction of farm buildings was converted back to agricultural zoning in exchange for de-zoning the forested borders. By February 2013, the eight one-acre parcels granted to the project were sold and one house had been built. ${ }^{9}$ Currently, a neighboring land trust is amenable to securing long-term tenure of arable land for Parc AgroVillageois residents interested in starting a small-scale agricultural enterprise.

In 2004, a locally owned 300-acre property zoned as non-agricultural was parceled into 25 lots to become the co-operative development project "Les fermettes du rang 13." The term "fermette" can be loosely translated as "farmstead” or "small farm," and "rang” as "rural road." The municipal council required that individual lots host small-scale agricultural or forestry projects. In 2007, a core group of committed individuals formed the Rang 13 solidarity co-op, whose charter emphasized sustainable development and reiterated its agricultural (preferably organic) vocation. The CDSE and the municipality collaborated with the co-op to develop the vision as well as to secure provincial funds to upgrade access roads and develop support programs and services for young families (MRC Mes Sources, n.d.). Rang 13 members

\footnotetext{
8 The cooperative was sold in part to attract young farmers to the area and to address financial challenges related to the employment structure.

${ }^{9}$ It is believed that the participants' strong collective identity carried the Parc Agrovillageois project. When it was “cut in half” to address the UPA's reservations, so too was the identity of the project. The project was said to have lost momentum because it could no longer be developed as it had been collectively imagined.
} 
purchased the land collectively at costs reflecting the size and the features of individual lots. Overall, the combination of endogenous resources (e.g., the capacity to welcome visitors, the work of volunteers, project coordination, etc.) and exogenous resources (e.g., networks at the local, regional, and national levels) brought the Rang 13 project to fruition (Dufresne, 2012). ${ }^{10}$ The original vision of the Rang 13 has not fully materialized since the majority of residents do not professionally engage in agricultural and forestry ventures, however many have contributed to the local food economy by launching new, albeit small-scale, food and forestry initiatives.

\section{Comparative analysis}

\section{Restraining factors}

SSI and Saint-Camille interviewees were asked to reflect on food system planning barriers and challenges in their communities. Table 1 summarizes the findings that emerged from these conversations and background research. Five themes common to both communities emerged from this comparative process.

Table 1: Barriers and challenges to project development

\begin{tabular}{|l|l|}
\hline \multicolumn{1}{|c|}{ Salt Spring Island } & \multicolumn{1}{c|}{ Saint-Camille } \\
\hline - Lack of funding and support & - Promoting agricultural diversification in the \\
- Unsupportive provincial and federal policy & context of unsupportive policies and \\
- Land availability and accessibility & institutions \\
- Housing & - Land access for the new farming generation \\
- Communication & - Growing a new generation of producers in a \\
- Development and application of local & shifting agricultural context \\
food policy & - Balancing the protection of agricultural land \\
- Local government structure & with maintaining vibrant communities \\
& - Dealing with pressure from the resource \\
& extraction industry \\
\hline
\end{tabular}

First, both Saint-Camille and SSI pointed to unsupportive provincial and federal policies and to institutional barriers. As a solidarity co-op, Saint-Camille’s La Clé des Champs was not eligible for support from La Financière Agricole (a provincial agency providing financial and

\footnotetext{
${ }^{10}$ Upon completion, more than 80 individuals are expected to live on the Rang 13 site, which alone represents a 17 percent increase in Saint-Camille's population. By 2013, the Rang 13 project had attracted 25 families from different regions, 75 percent of which were between 25 and 35 years old (MRC Mes Sources, n.d.).
} 
risk management tools in the agrifood sector), while the UPA-controlled supply-management system was seen as obstructing agricultural diversification. On SSI, policy changes such as the MIR were perceived as being developed primarily to address the needs of large-scale agribusinesses, to the detriment of SSI's small-scale farming operations. The absence of agricultural extension agents, funding for research, or infrastructure for SSI farmers were seen as further indications that policy-making and the allocation of funds were no longer geared towards supporting small-scale agriculture.

Second, the challenging conditions facing the new farming generation were a recurrent theme. The lack of available and accessible land and housing emerged as issues tied to multiple factors, including provincial and local zoning and regulations. SSI is home to numerous sensitive ecosystems that are protected by strict Islands Trust regulations. On the limited farmland, high land prices were a significant barrier to entry for potential new farmers. A lack of affordable farm housing, considered to be the result of a combination of local Islands Trust bylaws and ALC rules, was another limiting factor. In Saint-Camille, although the new generation was seen as capable and willing to develop viable businesses on smaller, more affordable acreages, there were multiple provincial regulatory impediments to dividing and building homes on these agricultural properties.

Third, developing and maintaining constructive and inclusive dialogue was a critical factor. A lack of communication with local regulatory bodies and challenges navigating the complexity of policy language impeded the SSIAA. Communication with the community had been crucial in gaining support for the abattoir project, whereas it is believed that a lack of communication inhibited the realization of the composting pilot project. In Saint-Camille, developing strategies to attract new food producers raised questions about the agricultural model desired by the community. On one hand it was widely believed that the conventional model must evolve to solve its systemic issues, although this perspective was tempered by the recognition that the livelihoods of numerous conventional producers depend on the existing system. On the other hand, community members aspired to an alternative approach to agriculture. Ensuring a healthy coexistence between the aspirations of conventional and alternative agriculture was a challenge, but Saint-Camille managed to foster a type of dialogue in which everyone could explore options and develop viable solutions, as opposed to becoming polarized proponents of competing models.

Fourth, both communities strove to find a balanced approach to translating local food and agriculture policies and projects into action in the face of other, at times competing, community priorities and regulatory processes. The SSI AFP helped integrate language supportive of local agriculture in the SSI Official Community Plan (OCP) review process. ${ }^{11}$ Still, translating the OCP into land-use applications, bylaws, and other practical actions, as well as navigating the

\footnotetext{
${ }^{11}$ For example, whereas one of the 1998 SSI OCP objectives was to "support farming as an important traditional land use, lifestyle and livelihood on Salt Spring Island” (Islands Trust, 1998, p. 39), the AFP recommendation to amend and modernize the OCP description of farming land use was accepted. The revised 2010 OCP now supports "farming as a social, cultural and economic priority and an ecologically responsible land use on Salt Spring Island" (Islands Trust, 2010, p. 45).
} 
various legal hoops and regulations, were significant challenges. ${ }^{12}$ Conducting feasibility studies and obtaining the required permits to establish facilities that support the expansion of agricultural activities was said to be complicated and consume time, energy, and resources. In Saint-Camille, residential properties on the real estate market were perceived as lacking attractive features (too close to main roads and poor solar orientation), while agricultural properties with attractive real estate characteristics are protected under Québec legislation. Failing to balance the preservation of agricultural land with maintaining vibrant communities can create community and land-use tensions. In the case of the Parc Agrovillageois, provincial legislation and regulations have restricted the capacity of Saint-Camille to develop alternative land-use models on properties zoned as agricultural, even in cases where food production was a central and defining feature of the project. $^{13}$

Fifth, limited jurisdictional power of local governments over local resources and matters that concern, and go beyond, local food and agriculture was another challenge identified at both sites. The Capital Regional District also includes more populous urbanized areas such as the city of Victoria; SSI's (regulatory and related) needs and priorities were perceived as competing against those of urban areas that may have more "weight" in the local government structure. Although tax rates on SSI are similar to the rest of the region, SSI (and the adjacent outer Gulf Islands) was said to have access to fewer services and supports delivered by the Capital Regional District. In the Saint-Camille area, Bowmore Exploration Ltd. announced in early 2011 that it would begin gold exploration activities. Under Québec law, a mining company granted a right to explore, develop, and exploit a mineral deposit can expropriate land, but the final say as to whether mining activity will be pursued ultimately lies with the provincial government. The municipality promptly resolved to reject any mining, oil, or gas project that would undermine the growth of the agricultural sector, including any development that included a risk of contamination or a negative impact on community food autonomy via the loss of agricultural land. The local "Mine de rien" ("mine of nothing”) committee was formed to ensure that the provincial mining legal framework would protect the interests of communities and the environment, and to establish a balance of power with the mining industry by informing citizens and defending their right to collectively choose the regional development model that they deemed most appropriate for their community (Comité Mine de rien, n.d.).

\footnotetext{
${ }^{12}$ The abattoir project illustrates this specific challenge: Because there was no property on the island zoned to host an abattoir, the abattoir is currently operating on a temporary-use permit and on leased land, which does not ensure long-term security.

${ }^{13}$ For example, the Parc Agrovillageois as originally conceived was welcomed by the CPTAQ and opposed by the UPA. Because the UPA primarily represents and defends the interests of the conventional agricultural sector, its priorities are not necessarily aligned with Saint-Camille's efforts to foster community economic development and to increase its population.
} 


\section{Supportive factors}

Table 2 lists three factors and practices that supported SSI achievements. Several reports establishing food-and-agriculture baseline data compiled information on, and brought together various facets of, the SSI food system. These reports were central to promoting agriculture on SSI in ways that promoted collaboration and created synergies and positive spin-off effects. Various strategic and project-specific plans drew from this data to illustrate the relevance of, and to justify the financial input required for, the proposed initiatives. This data also served to motivate the SSI community to support SSIAA activities.

Table 2: Circumstances and practices supporting key achievements

\begin{tabular}{|l|l|}
\hline \multicolumn{1}{|c|}{ Salt Spring Island } & \multicolumn{1}{c|}{ Saint-Camille } \\
\hline - Tracking of relevant & - The co-construction of knowledge and bridge building \\
indicators & - The CDSE: a long-term community-municipality partnership \\
- Using data to motivate & - Collective entrepreneurship \\
action & - Building community confidence in early stages \\
- AFP process and content & - Food autonomy and agricultural diversification in \\
& strategic plan \\
\hline
\end{tabular}

The inclusive AFP process was instrumental in achieving community support, buy-in, and ownership. The sense of pride in the AFP reported by some interviewees was attributed to its accurate reflection of community needs and priorities. The remarkable extent to which the AFP has been implemented was related to its having given the community a common vision to focus on, rally around, and channel energy and resources towards. The three priority recommendations were a vehicle for community engagement that allowed interest and excitement to translate into action. Other factors contributing to the AFP's traction included timing (the community was already mobilizing around food issues) and the prioritization of key projects. Early progress increased community confidence in the role and work of the SSIAA. Lastly, one Islands Trust Trustee, who was part of the AFP committee, faithfully and effectively supported the AFP implementation process from the beginning.

Five important factors and practices emerged from the Saint-Camille case study (Table 2). The creation of spaces for dialogue enabled Saint-Camille residents to build solidarity and collectively address community issues. By intentionally cultivating openness and fostering a learning ethos, Saint-Camille expanded its set of resources for local development and developed new collaboration opportunities. ${ }^{14}$ The CDSE developed projects, initiated community-based

\footnotetext{
${ }^{14}$ For example, in August 2012, Saint-Camille's community hub Le P’tit Bonheur and the research centre on social innovations (Centre de recherche en innovations sociales, or CRISES) at the Université du Québec à Montréal obtained provincial funding to develop a series of knowledge-sharing workshops bringing together researchers and
} 
reflection processes, and accompanied local citizens in community-driven initiatives. Through extra-local networks, elected representatives helped to secure financial assistance. They also provided the moral support essential to allow the CDSE to fulfill its mandate. One interviewee explained that:

...the municipality also fosters constant collaboration between organizations, and so in this sense it stimulates the synergy that materializes and the network that this collaboration has created.

This dual focus of creating dynamic interaction within local areas while bringing in perspectives and resources from the wider political and institutional environments illustrates what Shucksmith (2013) calls “networked development.” In this sense, dense local networks build social and economic capital, while strategic connections beyond the locality help position the territory to its best advantage. In Saint-Camille, citizens brought together the social benefits of collective action and the power of the local economy to support land-based development projects such as La Clé des Champs and "Le groupe du coin,” a local micro-financing investment association empowering small investors to invest locally. Project leaders and active participants engaged many other citizens in the development process by providing ample space to ask questions, expressing concerns, and reflecting on propositions during community forums. Residents reportedly welcomed the proposals because they were extensively consulted, and because common ground was established.

Elaborated in consultation with the community, Saint-Camille's 2008-14 sustainable development strategic plan explicitly includes community food autonomy and agricultural diversification as a means to increase the diversity and availability of local food products (Municipalité du Canton de Saint-Camille, 2008). Another central element of the plan, the concept of “communauté nourricière” (loosely translated as “nourishing community”) evokes several aspects of community autonomy and well-being, such as local services and employment, solidarity amongst citizens, a healthy environment, the capacity to utilize local natural resources, and a reduced dependency on external suppliers (Municipalité du Canton de SaintCamille, 2008).

\section{Discussion}

This comparative analysis indicates that Saint-Camille and SSI share at least eleven food system planning features:

Saint-Camille citizens. The more theoretically informed knowledge of the participating professors introduced new perspectives and critical insights, whereas the experiential knowledge of citizens nourished the reflections and analysis of the academics involved (Récits-Recettes, n.d.). By bridging the work of researchers and practitioners, the workshops have fostered innovation and helped to identify solutions to various challenges. 
1. Local governments focus on local food systems and agricultural plans.

2. Local governments support entities whose mandates and activities relate to food and agriculture.

3. Community plans integrate food system considerations into local policies and planning.

4. Community-based food and agriculture enterprises increase diversity and availability of local foods and maintain or develop local knowledge and capacity.

5. Food system data supports planning processes and projects, raises awareness, and fosters community involvement.

6. Participatory processes guiding community planning and communication foster community understanding and buy-in.

7. Social and physical infrastructure supports existing farmers, promotes the successful establishment of new farmers, and helps to bring consumers and producers closer together to co-create a more sustainable local food system.

8. Constraints posed by policies, regulatory bodies, and programs are addressed with informed advocacy.

9. Collective entrepreneurship shapes the local food system and builds community.

10. Partnerships of many kinds contribute to building local food systems.

11. Recognition is given to connections between multiple aspects of community health and the characteristics of local food and agriculture systems.

This discussion considers the coinciding features that were identified and explores how, in both Saint-Camille and SSI, local planning processes, policy, and community-led project developments reflect food sovereignty aspirations. Although neither community explicitly names food sovereignty as a guiding concept or goal, ${ }^{15}$ three key food sovereignty themes appear in food system change activities in Saint-Camille and SSI: a) local interdependence; b) selfdetermination and endogenous development; and c) the transformation of knowledge.

Exploring whether and how Saint-Camille and SSI are engaged in initiatives that overlap with or correspond to a food sovereignty framework is interesting because relatively little is known about how expressions of food sovereignty are shaped by local governance and

\footnotetext{
${ }^{15}$ Canadian local governments appear to shy away from openly and officially embracing the wider affirmation of the right to self-determination called for by Food Sovereignty. However, some communities in the United States are extending Food Sovereignty's right to self-determination into the territory of state law by defying the state on the sale of local foods. As of June 2013, ten Maine towns (Brooksville, Sedgwick, Penobscot, Blue Hill, Trenton, Hope, Plymouth, Livermore, Appleton, and Isle au Haut), two Vermont towns (City of Barre and Town of Barre) and a few California towns had passed Local Food and Community Self-Governance ordinances. Drafted in response to the US Food Safety Modernization Act, these so-called Food Sovereignty ordinances attempt to allow food producers and processors to sell their goods directly to consumers without state or federal oversight, thereby exempting them from state licensing and inspection laws, while pitting towns against state governments (Moretto, 2013; Wilce, 2011).
} 
community dynamics in Canada. Notable exceptions include: the work of Desmarais and Wittman (2014), who researched how groups of farmers, food activists, and Indigenous peoples use the food sovereignty discourse in Canada and identified that the shared goal of this wide range of actors is "to reclaim a public voice in shaping the food system" (p. 17); and Food Sovereignty in Canada: Creating Just and Sustainable Food Systems, edited by Desmarais, Wiebe, and Wittman (2011), a compilation of case studies examining a variety of grassroots initiatives through the food sovereignty analytical framework.

Beyond these contributions, the municipal planning perspective, especially in the rural context, is an aspect that has yet to be accounted for in researching what food sovereignty might look like "on the ground." One objective of the following discussion is to contribute to addressing this gap by drawing from the SSI and Saint-Camille examples. A second objective is to briefly consider the relationship and differences between community food system planning and more classical or recognized food sovereignty frameworks. A third objective is to introduce a thought experiment that further explores the possible implications of these findings.

\section{Local interdependence}

Both communities are pursuing local interdependence to increase resiliency and food autonomy. Schanbacher (2010) draws attention to how, in the contemporary food system, consumption is divorced from the production process. To explore how food sovereignty seeks to repair this schism, he describes how the Slow Food movement sets aside the producer-consumer dichotomy to center on the notion of "co-producers," a term which refers to consumers who make a political statement by taking an active interest in food producers, their methods, and the challenges they face. Co-producers, whether they are individuals, organizations, or institutions, have a greater stake in the production process. By actively developing an alternative relationship to food, coproducers are also engaging in the co-production of food and agriculture knowledge and capacity (Schanbacher, 2010). This co-production process knits both producers and consumers into a tighter social, ecological, and economic web that fosters more interdependence amongst food system actors. The commitment of Saint-Camille and SSI to become "co-producers" was reflected in the role of collective entrepreneurship in shaping the local food system (food system planning feature \#9) and the re-emergence of social and physical infrastructures that support new and seasoned farmers alike, and that bring consumers and producers closer together (feature \#7).

Food sovereignty also emphasizes that the social connections inherent in the production, consumption, and sharing of food are opportunities to reclaim control over the food system (Wittman et al., 2010). In Saint-Camille and SSI, community-based food and agriculture enterprises and organizations are increasing the diversity and availability of local products (feature \#4). These organizations and enterprises provide opportunities to reclaim control over the food system through maintaining and developing local food and agriculture knowledge. Both the social and physical infrastructure developed by residents of Saint-Camille and SSI can be viewed, following Sumner's (2012) definition of a sustainable food system, as being anchored 
within the public domain and involving an interdependent web of activities that build the civil commons. Strengthening the autonomy and resilience of more localized food systems also requires mutually supportive local, provincial, national, and international partnerships and policies (Pimbert, 2008). Both case studies revealed partnerships with local organizations as well as provincial entities that contributed to building local food and agriculture knowledge and capacity (feature \#10), yet interviewees also were able to identify and critique a number of unsupportive provincial and federal policies and programs.

\section{Self-determination and endogenous development}

Both communities were seeking more local control, which relates to the ways in which the search for food sovereignty is situated within a wider affirmation of the right to selfdetermination and endogenous development (Pimbert, 2008). Although some Saint-Camille and SSI interviewees saw the limited jurisdictional power of local governments as problematic, both communities were asserting their capacity and intention to engage in local food system planning by developing plans that integrated food system considerations into local policy-making and likewise positioned the local government and community as key players in shaping the local food system (feature \#3). Still, finding a balanced approach to translating policies and projects into actions in the face of other, at times competing, community priorities remains a challenge. Nonetheless, by supporting entities whose mandates include strengthening the local food system (feature \#2), and by advocating against constraints imposed by state policies, regulatory bodies, and programs (feature \#8), both communities were taking concerted action. Participatory planning contexts, another requirement for food sovereignty (Carney, 2012), also feed into selfdetermination and endogenous development processes. Saint-Camille and SSI both took substantive steps to implement participatory and inclusive approaches to community planning and project development (feature \#6).

\section{The transformation of knowledge}

Pimbert (2006) emphasizes that the endogenous development of locally controlled food systems requires transforming our ways of knowing by ceding more decision-making powers to local communities, promoting the democratization of research and diverse forms of co-inquiry, and expanding horizontal networks for autonomous and collective learning and action (Pimbert, 2006). Although Pimbert makes this argument primarily from a food production perspective, food sovereignty's call to transform ways of knowing is relevant to the broader context of food system planning. This has been observed in Saint-Camille and SSI, where both communities collected, disseminated, and integrated food system data into planning exercises (feature \#5), and where agricultural plans were used to assess the state of the local food system, identify 
opportunities, and develop strategies (feature \#1). In SSI and Saint-Camille, these features have served to empower civil society to engage with local food policy.

The complexity of environmental and bio-cultural food system interactions also calls for more holistic and transdisciplinary ways of knowing (Pimbert, 2006). The capacity to recognize and leverage new possibilities and synergies is at the heart of the food sovereignty paradigm. In both Saint-Camille and SSI, important connections between the development trajectory of local agriculture and other aspects of community health are recognized and reflected in community planning and project development (feature \#11).

\section{Food sovereignty planning?}

As shown above, three important food sovereignty themes can be seen within food system planning activities in Saint-Camille and SSI. This overlap raises the question as to whether the existing definitions and language attached to community food system planning (summarized at the beginning of this paper) adequately capture the full breath of aspirations and potentials inherent in food system planning practices and processes that have been observed in places such as Saint-Camille and SSI.

Whereas the SSI and Saint-Camille case studies demonstrate the integration of transformational elements based on bottom-up planning and development processes, and on calls for granting power to communities to shape their own food systems (both of which are core elements of food sovereignty discourses), the community food system planning language is by comparison more politically neutral and primarily focused on producing specific, middle-range outcomes. In other words, local interdependence, self-determination and endogenous development, and the transformation of knowledge politics go well beyond the community food system planning framework when it is understood only as the integration of food system considerations into community planning processes, projects, and policy development. By way of beginning to address this limitation, I propose a brief thought experiment to consider "food sovereignty planning" as a potentially fertile space that occupies the conceptual overlap between food system planning and food sovereignty. In the context of this exploration, food sovereignty planning is presented as the integration of food sovereignty principles into planning, policymaking, and programming at any level of government and in any governance process.

Engaging in food sovereignty planning signifies employing a food sovereignty lens in community food system planning, and thus an alternative approach to local government and community involvement in framing, envisioning, and implementing food system change. Both community food system planning and food sovereignty concepts strive for the emergence of a sustainable food system through multi-level governance interventions. What differentiates the two is that the food sovereignty language more explicitly places social justice considerations at the centre of food system change, names the political and economic power relations inherent in the global food system, and takes a political stance in the current debate concerning the advantages, shortcomings, and future of the contemporary global food system. The goal of food 
sovereignty is also to reclaim a public voice and more local control in shaping the food system (Desmarais \& Wittman, 2014; Wittman et al., 2010), a process that also may be informed or supported by the framework offered by food sovereignty planning.

Food sovereignty planning also echoes the theory of civic agriculture presented by Lyson (2004; 2007) as a new paradigm under which broader social objectives, beyond narrowly defined economic agendas, drive agricultural development, and where food and agriculture endeavours are engines of local economic development integrally related to the community's social and cultural fabric. Civic agriculture can be understood as "a broad based movement to democratize the agriculture and food system" (Lyson, 2007, p. 19) that must go beyond providing economic and market-based solutions, and embrace commonly held and non-profit spaces in order to reach a more holistic integration of people in place (DeLind, 2002).

A food sovereignty planning approach may also respond to the notion that the municipal movement into food-related issues could be part of a reaction to the loss of national powers in globalization processes (MacRae \& Donohue, 2013). It may assist towns and rural communities to develop their capacity to buffer themselves against, or directly challenge, the dominant neoliberal models of industrial agriculture and free trade. The capacity of communities to shelter themselves from the global food system is another tenet of the civic agriculture framework. Community empowering characteristics attributed to civic agriculture include locally oriented agricultural and food production, the integration of farming and food production into regional economies and local communities, a focus on quality products, labour and land intensive production practices (less capital intensive and land extensive), reliance on local and shared knowledge, and direct market links (Lyson, 2004), all of which are reflected to various degrees in the SSI and Saint-Camille case study findings.

Because food sovereignty unequivocally values food providers, food sovereignty planning may also uniquely capture the needs, constraints, and aspirations of the rural communities that are home to the majority of Canadian food producers. Finally, it is possible that integrating food sovereignty considerations into food system planning would bolster the potential of planning activities to support meaningful changes in the well-being, living environments, and livelihood choices of local residents.

\section{Nuances}

Whereas this paper focuses on the abilities of rural communities to engage in (re)shaping their local food system — an important component of food sovereignty — multiple other components of food sovereignty are not addressed. Food sovereignty has been discussed in the literature as a holistic concept that demands profound systemic changes on multiple fronts in order to be realized (Desmarais \& Wittman, 2014; Patel, 2009; Pimbert, 2008; Schanbacher, 2010; Wittman et al., 2010; 2011). It is important to understand “food sovereignty planning” as pointing to features and processes aligned with key elements of the food sovereignty framework, 
as opposed to a final state in which food sovereignty, in all its complexity and multiple layers, has been achieved through community planning.

This research did not identify substantive tensions within SSI and Saint-Camille related to the described food system initiatives. However, in theory, the full expression of food sovereignty planning could be expected to result in the emergence of tensions whose intensity is closely linked to the depth to which communities are willing to engage with the food sovereignty concept. The level of awareness of the breadth and history of the concept may play a significant role in shaping this depth of engagement. This points to an opportunity for food sovereignty planning to help bridge theory and action within food system change.

\section{Conclusion}

This paper builds on food system planning research by documenting and comparing the ways in which the two small rural communities of Saint-Camille and SSI engage in food system planning. The investigation of challenges and best practices leads to the identification of 11 food system planning features common to Saint-Camille and SSI. These 11 features suggest the presence of food sovereignty themes in governance planning processes, project development, and community-led initiatives. This research draws on food sovereignty theory (Carney, 2012; Pimbert, 2006; 2008; Schanbacher, 2010; Wittman et al., 2010) to identify three key food sovereignty themes present within food system change activities in Saint-Camille and SSI, namely: local interdependence; self-determination and endogenous development; and the transformation of knowledge.

The term food sovereignty planning is introduced in response to the-sometimes unrecognized and under-theorized-connections between community food system planning and the food sovereignty frameworks. Placing food sovereignty concerns closer to the heart of planning processes may provide useful bridges between advocacy and planning in the community food system context, which may increase the potential of planning activities to build just and sustainable food systems. However, additional research is needed to conceptually elaborate and evaluate food sovereignty planning as a planning framework for local rural governments. More specifically, there is a need to go beyond agriculture and "farmlands" to include Indigenous food systems and the notion of "foodlands," ${ }^{16}$ whereby the activities and traditions of hunting, fishing, and gathering may be part of community planning processes.

\footnotetext{
16 The term “foodlands" has been used for several years by the Capital Region Food and Agriculture Initiative Roundtable (CRFAIR) to emphasize the importance of recognizing, respecting and promoting Indigenous food systems in achieving a sustainable agricultural sector and food system in British Columbia. The CRFAIR is an organization working towards strengthening the regional food system and community food security.
} 


\section{Acknowledgment}

The research presented in this paper was conducted as part of the author's master's thesis, obtained from the Individualized Program at Concordia University (Montréal) in 2014.

\section{References}

American Planning Association. (2013). Planning and community health research center. Retrieved from https://www.planning.org/nationalcenters/health/

Apparicio, P., Cloutier, M.S., \& Shearmur, R. (2007). The case of Montréal's missing food deserts: Evaluation of accessibility to food supermarkets. International Journal of Health Geographics, 6 (4), 1-13.

BC Ministry of Agriculture. (n.d.) Agricultural area plans. Retrieved from http:/www2.gov.bc.ca/gov/content/industry/agriculture-seafood/agricultural-land-andenvironment/strengthening-farming/agricultural-area-plans

Béïque, J. (2011). Saint-Camille, le pari de la convivialité. Montréal: Les Éditions Écosociété.

Blay-Palmer, A. (2009). The Canadian pioneer: The genesis of urban food policy in Toronto. International Planning Studies, 14(4), 401-16.

Carney, M. (2012). "Food security” and “food sovereignty”: What frameworks are best suited for social equity in food systems? Journal of Agriculture, Food Systems, and Community Development, 2(2), 71-87.

Comité Mine de rien. (n.d.) Comité Mine de rien. Retrieved from http://www.orenestrie.com/ CPTAQ. (2007). Mission et mandat. Retrieved from http://www.cptaq.gouv.qc.ca/index.php?id=27\&MP=74-147

de la Salle, J., \& Holland, M. (2010). Agricultural urbanism: Handbook for building sustainable food and agriculture systems in 21st century cities. Winnipeg: Green Frigate Books.

DeLind, L. (2002). Place, work and civic agriculture: Common fields for cultivation. Journal of Agriculture and Human Values, 19 (3), 217-24. 
Desjardins, E., Lubczynski, J. and Xuereb, M. (2011). Incorporating policies for a healthy food system into land-use planning: The case of Waterloo Region, Canada, Journal of Agriculture, Food Systems \& Community Development, 2(1):1-13.

Desmarais, A.A. (2008). The power of peasants: Reflections on the meanings of La Vía Campesina. Journal of Rural Studies, 24(2), 138-49.

Desmarais, A.A. (2002). Peasants speak - The Vía Campesina: Consolidating an international peasant and farm movement. Journal of Peasant Studies, 29(2), 91-124.

Desmarais A.A., \& Wittman, H. (2014). Farmers, foodies and First Nations: getting to food sovereignty in Canada. Journal of Peasant Studies, 41 (6), 1153-73.

Dufresne, C. (2012). Une communauté apprenante, innovant et solidaire: Un modèle porteur de dévelopemment rural. Saint-Camille: Laboratoire rural de Saint-Camille.

Freedgood, J., Pierce-Quinonez, M., \& Meter, A.K. (2011). Emerging assessment tools to inform food system planning. Journal of Agriculture, Food Systems, and Community Development, 2 (1), 83-104.

Islands Trust. (2010). 2010 Salt Spring Island official community plan. B.6.2.1.1.

Islands Trust. (1998). 1998 Salt Spring Island official community plan. B.6.1.1.1.

Larsen, K., \& Gilliland, J. (2008). Mapping the evolution of 'food deserts' in a Canadian city: Supermarket accessibility in London, Ontario, 1961-2005. International Journal of Health Geographics, 7 (16), 1-16.

Lair, R. (2011). Études de cas des pratiques sociales innovatrices en agriculture. Cégep de Victoriaville: Centre d'innovation sociale en agriculture (CISA).

Lyson, T. (2007). Civic agriculture and the North American food system. In C.C. Hinrichs \& T.A. Lyson (Eds.), Remaking the North American Food System,(pp. 19-32). Lincoln and London: University of Nebraska Press.

Lyson, T. (2004). Civic Agriculture: Reconnecting Farm, Food, and Community. Medford (MA): Tufts University Press. 
MacRae, R., \& Donahue, K. (2013). Municipal food policy entrepreneurs: a preliminary analysis of how Canadian cities and regional districts are involved in food system change. Canadian Agri-Food Policy Institute.

MAMROT. (2012). MRC acteurs et processus. Retrieved from http://www.mamrot.gouv.qc.ca/amenagement-du-territoire/guide-la-prise-de-decision-enurbanisme/acteurs-et-processus/mrc/.

Masselink Environmental Design. (2008). Salt Spring Island Area Farm Plan. Retrieved from http://masselinkdesign.com/pdf/reports/SSI\%20Area\%20Farm\%20Plan.pdf

Meter, K. (2011). Seventeen reasons to do food assessments. Journal of Agriculture, Food Systems, and Community Development, 2 (1), 7-9.

Mendes, W. (2007). Negotiating a place for 'sustainability' policies in municipal planning and governance: The role of scalar discourses and practices. Space and Polity, 11 (1), 95-119.

Mendes, W. (2008). Implementing social and environmental policies in cities: The case of food policy in Vancouver, Canada. International Journal of Urban and Regional Research, 32 (4), 942-67.

Ministry of Agriculture and Lands. (2006). Salt Spring Island land use inventory report. Victoria: Government of British Columbia.

Moretto, M. (2013, March 11). Brooksville becomes ninth town to defy state on sales of local food. The Bangor Daily News. Retrieved from http://bangordailynews.com/2013/03/11/news/hancock/brooksville-becomes-ninthmaine-town-to-defy-state-on-sales-of-local-foods/

MRC Mes Sources. (n.d.) Parts privilégiés participantes. Retrieved from http://www.messources.org

Municipalité du Canton de Saint-Camille. (2008). Vivre et agir ensemble: Plan stratégique pour un développement durable à Saint-Camille. Municipalité du Canton de Saint-Camille.

Nyéléni Declaration (2007), Sélingué, Mali. Retrieved from http://www.worldgovernance.org/article72.html?lang=en

Patel, R. (2009). Food sovereignty. Journal of Peasant Studies, 36(3), 663-706. 
Pimbert, M. (2008). Towards food sovereignty: Reclaiming autonomous food systems. London: International Institute of Environment and Development.

Pimbert, M. (2006). Transforming knowledge and ways of knowing for food sovereignty. London, UK: International Institute for Environment and Development (IIED).

Pothukuchi, K. (2000). The food system: A stranger to the planning field. Journal of the American Planning Association, 66(2), 113-24.

Pothukuchi, K., \& Kaufman, L.J. (1999). Placing the food system on the urban agenda: The role of municipal institutions in food systems planning. Journal of Agriculture and Human Values, 16, 213-24.

Pronovost, J. (2008). Agriculture et agroalimentaire: Assurer et bâtir l'avenir. Québec (QC): Commission sur l'avenir de l'agriculture et de l'agroalimentaire québécois.

Raja, S., Born, B., \& Russell, J.K. (2008). A planner's guide to community and regional food planning: Transforming food environments, facilitating healthy eating. Chicago (IL): American Planning Association.

Récits-Recettes. (n.d.) Ateliers des savoirs partagés. Retrieved from http://recitsrecettes.org/sites/default/files/Ateliers-savoirs-partages-Description-projet.pdf

Reichert, P. (2012). Salt Spring Island farm produce centre plan. Retrieved from http://plantofarm.org/resources/2012-produce-centre-plan

Reichert, P. (2006). Salt Spring Island food security report. Salt Spring Island: Salt Spring Island Community Services.

Reichert, P., \& Thomson, M. (2010). Salt Spring Island livestock production study. Retrieved from http://plantofarm.org/?s=livestock+production+study

Schanbacher, W.D. (2010). The politics of food: The global conflict between food security and food sovereignty. California: Praeger.

Shucksmith, M. (2013). Future Directions in Rural Development? Carnegie UK Trust. Retrieved from http://www.carnegieuktrust.org.uk/CMSPages/GetFile.aspx?guid=545a7523-4da8$\underline{\text { 4ff7-95e6-dd912abc6373 }}$ 
Smoyer-Tomic, E.K. Spence, C.J., \& Amrhein, C. (2006). Food deserts in the prairies? Supermarket accessibility and neighborhood need in Edmonton, Canada. The Professional Geographer, 58(3), 307-26.

Sumner, J. (2012). Conceptualizing sustainable food systems. In M. Koc, J. Sumner, \& A. Winson (Eds.), Critical perspectives in food studies (pp. 326-36). Toronto: Oxford University Press.

Wilce, R. (2011, October 10). Local Food Ordinances from Maine to California. PRWatch.org. Retrived from http://www.prwatch.org/news/2011/10/11034/local-food-ordinances$\underline{\text { maine-california }}$

Wittman, H. (2009). Reworking the metabolic rift: La Via Campesina, agrarian citizenship, and food sovereignty. Journal of Peasant Studies, 36(4), 805-26.

Wittman, H., Desmarais, A.A., \& Wiebe, N. (2010). Food sovereignty: Reconnecting food, nature and community. Black Point (NS): Fernwood Publishing.

Wittman, H., Desmarais, A.A., \& Wiebe, N. (2011). Food sovereignty in Canada: Creating just and sustainable food systems. Black Point (NS): Fernwood Publishing.

Woods, M. (2003). Deconstructing rural protest: The emergence of a new social movement. Journal of Rural Studies, 19(3), 309-25. 